\title{
Tourism border-making:
}

\section{A political economy of China's border tourism}

\begin{abstract}
:
This paper identifies changes in borderland tourism and their bordering consequences on the Daluo-Mongla border in Xishuangbanna, China. It identifies three distinctive phases: (a) phase one (1991-2001)- rapid growth of organized cross-border tourist flow, (b) phase two (2002-2011)- stagnation and collapse of formal tourism sector yet emerging illegal cross-border tourist flow, and (c) phase three (2012-present)resurrection and transition of border tourism. It illustrates the border-making agency of tourism, arguing tourism development at the border can be viewed as a re-bordering force. It analyzes an evolutionary process of changing power structures, namely a dominant control of local states and market forces, a partial power shift towards national state and border communities, and a new dominance by the Chinese state.
\end{abstract}

Keywords: tourism, bordering, ethnographic approach, ethnic minorities.

\section{INTRODUCTION}

Borders are traditionally regarded as barriers for tourism, for they were originally constructed for the purpose of producing barriers to human interaction and mobilities including the flow of people, goods, services, and ideas between countries (Weidenfeld, 2013). They served to mark patterns of judicial authorities and identities to formulate differences between peoples. Yet in an era of globalization, borders are now viewed more frequently as bridges enabling contact, communication, openness and collaboration (Johnson et al., 2011; Newman, 2006). Against such a backdrop, tourism has emerged in many borderlands worldwide (Gelbman \& Timothy, 2017). Notably, given the complex, typically interstitial, liminal character of border zones, border tourism constitutes a distinct intermediary type of tourism, neither domestic nor international (Askew \& Cohen, 2004).

It is suggested that to understand China it is necessary to understand policies relating 
to its borders. China is the "Middle Kingdom" - hence its cultural vision and the very calligraphic denoting China represents a country where borders have significance (Jacques, 2012). For centuries China sought to protect its borders as lines of demarcation between the civilized and non-civilized worlds - today borders are embedded in broad socio-economic and political contexts (Megoran, 2012; Timothy, Saarinen, \& Viken, 2016). Borders are thus not given, but socially made and continually remade by multi-scalar actors in evolving contexts, during which power struggles are unavoidable (Scott, 2015) .

To this end, the bordering process is thus inextricably interweaved with tourism development on the border (Novak, 2016). Yet, due to a static view of borders as "lines" of states in tourism scholarship (Timothy et al., 2016), the tourism and bordering nexus remains almost unexplored (Rowen, 2014). While the case focuses on the Yunnan Myanmar border region, for the most part the Central State policies noted refer to the whole of China and processes similar to those of Yunnan can be found in Xinjiang, Tibet, and Gansu for example.

From this aspect, the political economy of tourism development at the border appears a potential means of analysis. "Political economy comprises the study of the socioeconomic forces and power relations that are constituted in the process of the production of commodities for the market and the divisions, conflicts and inequalities that arise from this" (Bianchi, 2018, p. 88). Within a political economy approach, the social system is considered to constitute a whole, all aspects of which are viewed as interconnected with the broad economic and political environment (Jessop, 2008). This approach emphasizes how economic and political conditions shape power relationships among actors, and thus contributes to understanding how the development of tourism at destinations involves highly politicized power relations among multiple stakeholders, each of whom seeks to shape the tourism system in their favor (Stoffelen, Ioannides, \& Vanneste, 2017), and further the social consequences of tourism. Hence the political economy of border tourism development can facilitate the identification of the multi- 
scalar and power-infused social processes that shape borders and, at the same time, are shaped by borders.

This study assesses the development of tourism bordering within the distinctive sociopolitical and economic circumstances of China. These have driven tourism development since the "Opening-up", including a gradualist approach to transition/transformation, the re-birth of entrepreneurship and the market economy, structural change and the retention but evolution of governance by the Chinese Communist Party (Sofield \& Li, 2011). During the late 1980s and early 1990s, China signed a number of agreements with neighboring countries to promote border tourism development for peoples on both sides of the borderlands, which has now been at an "integrated" development stage as envisioned by the national strategy (Ge, Xi, \& Wang, 2014). Nonetheless, empirical studies of tourism at China's borders remain relatively few despite significant policy actions over the last 40 years (Li \& Shu, 2015). Taking the Daluo-Mongla border in China's Xishuangbanna as a case study, this paper seeks to comprehend the complexity of socio-economic and political changes accompanying China's border tourism development and its consequences over a period of nearly 30 years. In doing so it highlights border tourism in areas of ethnic minority populations.

\section{LITERATURE REVIEW}

Border, bordering, and tourism

The role of border in tourism has generally been well investigated, including borders as destinations and attractions, impediments, landscape modifiers, and spaces of transit (Timothy, 2001; Timothy et al., 2016). According to Timothy (2001), tourist attractions related to borders and border areas include, but are not limited to, border-themed attractions, heritage tourism, vice (e.g., gambling, prostitution), natural attractions and international parks, shopping, political and socio-cultural difference across the border etc. Therefore, tourism activities and attractions can be diverse within and across borderlands, yet "in essence, they pertain to the border existence or demonstrate a conceptual relationship between them and the border" (Mansfeld \& Korman, 2015, p. 
437). Thus, as Mansfeld and Korman (2015) point out, the term "border tourism" should be adopted as an umbrella term covering all borderland tourism types and attractions established as a result of the existence of and in relation to the border. Border tourism (bianjing lvyou), however, as defined by the Chinese central government, requires travel agencies to be licensed. This permits them to serve Chinese citizens and citizens of neighboring countries to collectively cross borders at appointed "border ports" (bianjing kou'an) in accordance with regulations pertaining to travel within defined areas and time limits as agreed by bilateral government agreements (China National Tourism Administration, Ministry of Foreign Affairs, Ministry of Public Security, \& General Administration of Customs, 1997). Therefore, Mansfeld and Korman's (2015) definition is doubtless broader and is adopted here to permit a holistic view of tourism on China's border.

Yet, when it comes to the role of tourism in border-making, research remains scarce. This is not surprising as a static view of the border as "lines" limits the depth and scope of examining the impact of tourism on the border. Timothy, Guia, and Berthet (2014), for example, propose a typology of tourism-induced changes to borders, including subsequent tourism, wrapping of a resource, heritagisation of borders, modification of infrastructure, and territorial exchange. The focal point of this typology, however, is still the physical border. In this respect, more recent studies (e.g., Rowen, 2014; Timothy et al., 2016) are calling for a shift towards the bordering perspective.

The bordering perspective re-orients attention from border per se to the process of the multi-scalar production of borders as being socially constructed (Newman, 2006).Yet, "the term bordering does not imply a specific trend (towards opening or closure) but refers to all the practices (from everyday life to high geopolitics and geo-economics) that relate to the continuous making and remaking of borders" (Herzog \& Sohn, 2017, p. 5). Two associated bordering dynamics are de-bordering and re-bordering, which not only contest each other, but also interact and co-mingle. De-bordering signifies the "opening of a border, the disabling of controls or the blurring of the differences between 
social and spatial entities and the mental categories associated to them"; Re-bordering, however, highlights the "controlling of movements and flows and the construction of categories and distinctions that structure social and spatial divisions" (Herzog \& Sohn, 2017, p. 5).

Indeed, one can find some evidences from extant literature regarding the relevance of tourism and bordering. On the one hand, it is argued that de-bordering and re-bordering at macro-level (a state-centric perspective) has a profound impact on border tourism development. One notable example is in Mansfeld and Korman's (2015) conceptual model regarding conflict-heritage tourism in border areas where the level of development is mainly dependent on border permeability as determined by the relations existing between nation-states. On the other hand, several empirical tourism studies at micro-level (borderland-centric perspective) have implicated the potential role of tourism in the bordering process. For example, Russian second-home development in the Finnish borderland was partly enabled by the liberation of Finnish-Russian border after the Soviet Union's collapse. Hannonen (2017) states this reinforced the symbolism and mental distance of the Finnish-Russian border among Finnish borderlanders as Russian owners were “othered”. Prokkola's (2010) study, however, argued that crossborder co-cooperative tourism development on the Finnish-Swedish border significantly contributed to the reorganization of border landscape and dissolution of mental boundaries in the region.

\section{Tourism as an agent of border-making: An analytical framework}

With a process-based understanding of borders, border scholarship, essentially drawing on the insights of Henri Lefebvre, has highlighted the social production of border space (Rossiter, 2011), which can be a useful starting point to capture the "processual" interactions between tourism and border construction. Within this spatial approach, border can be viewed through three interdependent and inter-reactive moments of space - the conceived, perceived, and lived (Dean, 2005). The conceived dimension considers how the border is represented by those in power. Hence, state discourse and 
representation related to the border continue to play a critical role in structuring border realities (Brunet-Jailly, 2005). Yet one must point out that the state is not a homogenous entity, and that authorities at different levels are not necessarily consistent with each other in regards to the border (Kraudzun, 2017). Market forces are another major factor in terms of tourism, and representation of the border translates to the industry's construction of the border as well as tourists' imagination of the border ( $\mathrm{Su}, 2010)$.

The lived dimension is about everyday life at the border, which is directly and significantly affected by proximity to the boundary. While the dominant forces try to shape border realities through corresponding discourses and practices, borderlanders are never passive actors. Instead, their agency, resistance, contestation etc. form a significant discourse in recent border scholarship as shaping new social understandings of the border (Singh, 2014). To interrogate how tourism might shape the everyday life at the border, three lenses can be drawn from extant literature. The first is the host-guest interaction that has been explored extensively in tourism (Aramberri, 2001). Second, the original social structure and relationships in the host communities might be affected by tourism, which then results in consequential impacts on the community's daily experience (Weng, 2011). Last but not least, as the borderland is located between different nation-states by definition, the cross-border interaction (formal and informal) can be an integral part of border people's everyday life (Ghosh, 2011) in which tourism, with its flows of people, goods, investment etc. across the border, clearly has a role.

The perceived dimension draws attention to the production/consumption/regulation practices of various actors that result in physical border landscape (Frisvoll, 2013; Sofield, 2006), which is an observable manifestation of bordering practices and their impacts on a particular border (Johnson et al., 2011). Tourism clearly has a role in this aspect, notably demonstrated by the aforementioned typology of tourism-induced changes to borders. An analytic framework is thus established to unravel the bordermaking agency of tourism (Figure 1). It allows a nuanced examination of the interaction and mutual constitution of structure and agency in tourism border-making process, 
avoiding the simple top-down vis-à-vis bottom-up models of hegemony/structure and resistance/agency towards border(ing).

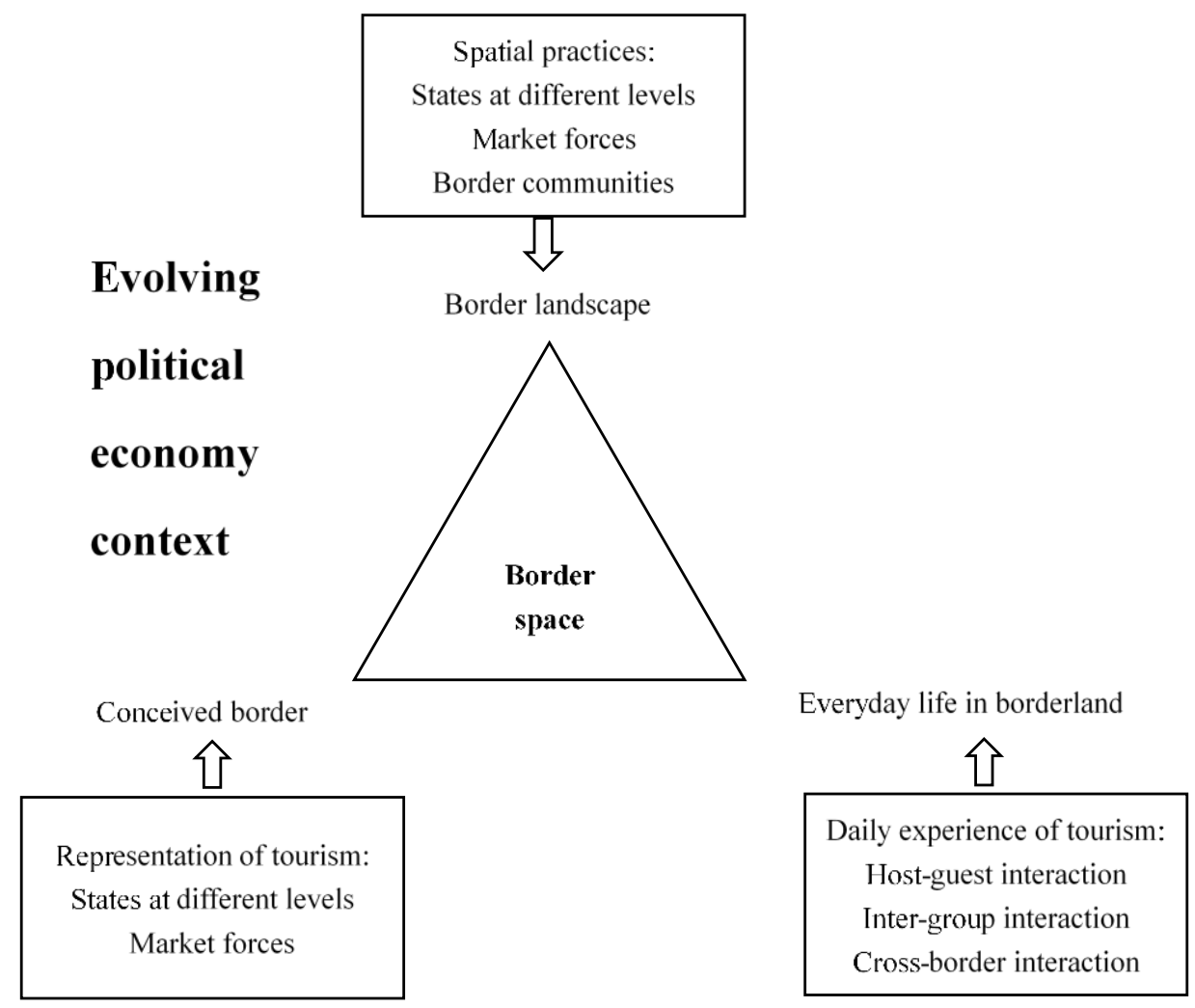

Figure 1 Tourism border-making: An analytic framework

\section{THE CASE- DALUO ON THE XISHUANGBANNA-MYANMAR BORDER}

Xishuangbanna Dai Autonomous Prefecture, located in Southwest China's Yunnan province, bordering Myanmar and Lao, is among the best-known tourist destinations in China. Covering an area of 19,124.5 square kilometers, and colloquially known as Banna, the prefecture comprises three administrative subdivisions, namely Menghia county in the west, Jinghong city (county-level city) in the center, and Mengla county in the east. With a resident population of 1,164,000 at the end of 2015, the prefecture is home to 13 officially recognized ethnic groups. The ethnic minorities account for $77.6 \%$ of the registered population, while Han Chinese account for $22.4 \%$ (Government of Banna, 2016). 
Tourism in Banna started in the early 1980s and Banna was listed as one of forty-four national-level scenic sites by the Chinese government in 1982 (Yang, Wall, \& Smith, 2008). In general, the area has been known for its ethnic minorities (notably Dai), tropical environment, and border landscape. The domestic tourism market is mainly Han Chinese from developed areas of China, notably the provinces of East China, while a small international market comprises tourists from Southeast Asia, mostly Thai (Bi \& Yang, 2017; Yang et al., 2008). As shown in Figure 2, the tourism market grew rapidly in the 1990s, followed by a period of stagnation in the early 2000s. That stagnation was mainly caused by a series of underlying issues in local tourism planning and management (Yang et al., 2008), for which the huiyong trend (the commission-oriented behaviors and operations among tour guides, travel agencies, tourism enterprises managing tourist sites, and souvenir businesses) was greatly blamed for impairing tourists' experience and damaging the image of Banna. Following reforms as described below, tourism has become a pillar of the local economy for some years, annually contributing over $60 \%$ to the regional GDP (Bi \& Yang, 2017).

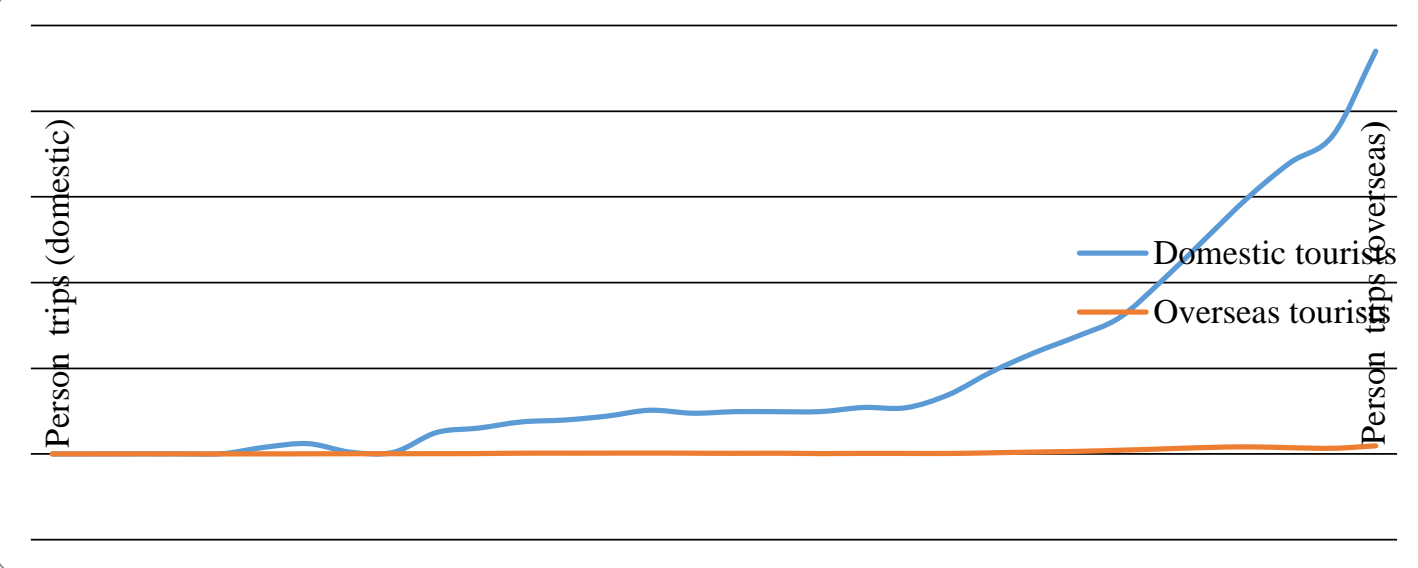

Figure 2 Annual tourist arrival in Banna (1985-2016)

Source : Banna Tourism Administration

The border tourism program in Banna formally started in 1992 covering the ChinaMyanmar border in Daluo-Mongla area and the China-Laos border in Mohan-Boten 
area. However, tourist flows in the borderlands of China and its neighbors is mainly unidirectional, with mostly Chinese tourists visiting these areas, even in Hong Kong and Macau. Tourist flows in the above mentioned borderlands once accounted for over two thirds of the total border tourists in Yunnan province, making Banna an important border tourism region in China (Center for Tourism Planning and Research of Sun Yatsen University \& Banna Tourism Administration, 2003). However, at the end of 2004, the border tourism program in Yunnan, and later nationwide, was suspended for Chinese citizens, which remained so for most parts of China's borders till 2013 with the exceptions of the special administrative regions.

The Daluo-Mongla border (see Figure 3) constitutes a focal point for this paper because: (a) Tourism there has long been more popular and has a more overt presence than in similar areas of ethnic minorities; (b) Tourism there has been a major force for social change (Li, 2009); (c) Tourism there is considered as emblematic of China's border tourism development ( $\mathrm{Li}, 2014$; Xie, 2005), and the fact that indigenous peoples there (e.g., Dai, Bulang, Hani) straddle the national border is common in Asian borderlands (Van Schendel \& De Maaker, 2014) as in Xinjiang; (d) It is at the border crossings that the different forces of bordering dynamics are most vibrant (Herzog \& Sohn, 2017), and hence the entanglement of tourism and bordering is more observable there.

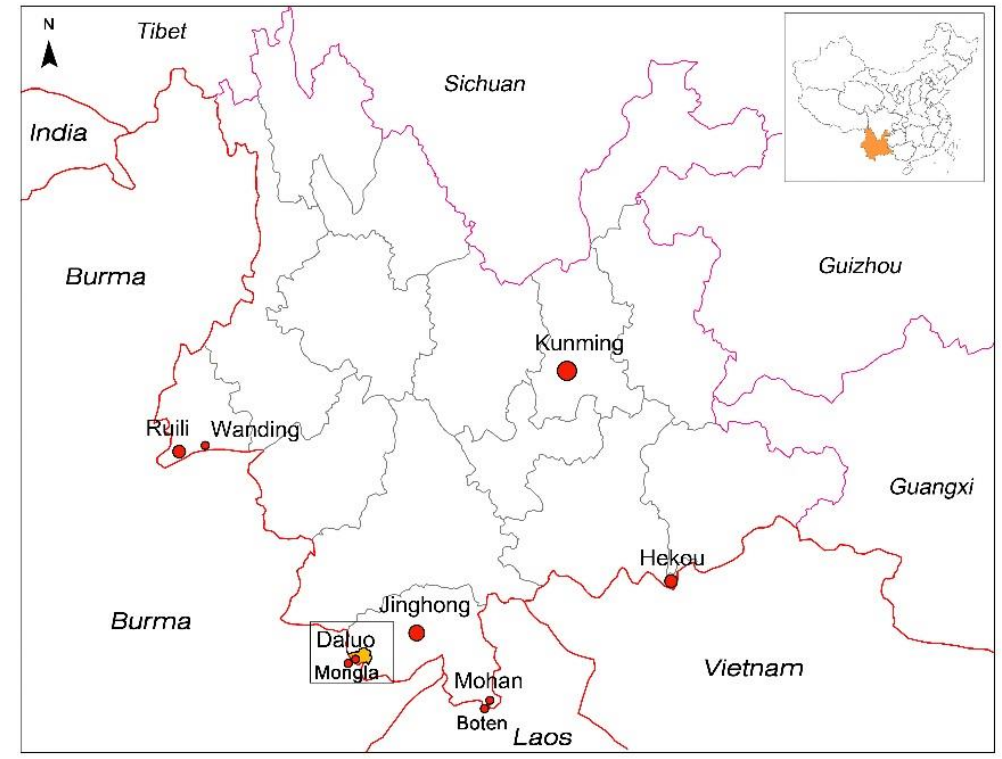

Figure 3 Research site 


\section{METHODOLOGY}

The study adopted an ethnographic approach and data were collected via four months' fieldwork by the first author in four consecutive years: July-August 2014, OctoberNovember 2015, March-April 2016 and June-July 2017. The months were spent living with a Dai family in a tourist village, and researching in the Daluo-Mongla border crossing area, yet occasionally traveling to Menghai county town and Jinghong to interview respondents there.

This meant that the first author entered into a social pattern different to the space he normally occupies, which, according to Ryan (2012), requires more intense periods of learning. It should be noted that the second author also has some familiarity of the area. This process supported a micro-level analysis of everyday life at the border, an advantage of the ethnographic approach to research (Fetterman, 2010). In fact, Dean (2012) argues, ethnographic study is the only way to research borderlands as "lived spaces challenged and inspired" by international boundaries.

First-hand data were collected via observation, conversation and interviews. In-depth interviews were conducted with four government officials from the prefecture to the county to the town level, whose expertise in border management or/and (border) tourism ranged from 11 to 30 years. Initial analysis of government policies, documents, and planning materials related to border and tourism was also conducted to help the first author familiarize himself with the context as well as raising questions for the interviews. The officials were then purposefully contacted via the authors' personal networks. Each was interviewed at least twice and were willing to share their abundant knowledge of local government policies and practices concerning (border) tourism. All were recorded and later transcribed.

Forty-four indigenous villagers were interviewed (Table 1). A snowballing sampling 
was adopted, as it proved to be the quickest way to gain respondents' trust. The fact that Dai villager respondents accounted for the largest percent can be justified as follows: (a) The border crossing is located at the Daluo administrative village $\left(33.95 \mathrm{~km}^{2}\right)$ where 10 out of the 13 villages are Dai villages, the other three being one Bulang village, one Hani village, and one migrant village; and (b) Dai live in the lowlands, and are more involved in tourism compared to upland Bulang and Hani people. In the upland villages, purposeful conversational approaches were adopted. For those interviews/conversations with indigenous ethnic minorities, questions usually related to local history, ethnic culture, personal history, livelihood, cross-border interaction and attitudes towards tourism. These interviews (often repeated) were usually conducted in villagers' homes, and it often happened that while interviewing a respondent, family members and friends who had dropped in would join the conversation, making the interview an informal focus group interview. In total, 37 formal interviews were recorded.

Table 1 The socio-demographic characteristics of the indigenous villager sample

\begin{tabular}{lccccc}
\hline \multicolumn{2}{l}{ Socio-demographics } & Frequency & Socio-demographics & Frequency \\
\hline \multirow{2}{*}{ Gender } & Male & 30 & & Tourism employees & 7 \\
& & & Job & Self-employed in tourism & 13 \\
& Female & 14 & & Agriculture-related livelihoods & 24 \\
\multirow{4}{*}{ Age } & Middle 10s to 30s & 26 & Dai & 35 \\
& 40s-50s & 13 & Ethnicity & Bulang & 6 \\
& 60s and above & 5 & & Hani & 3 \\
\hline
\end{tabular}

Twenty-one migrants were also interviewed, including fourteen migrant villagers/workers/businessmen, four tourism managers, and three investors, and nineteen of these interviews were recorded. Moreover, three high ranking Dai Buddhist monks in the town, four respondents from the tourism industry from out of town and one tourism researcher with expertise in the area were also interviewed. Five were recorded. The interviews were semi-structured but tailored to suit particular individuals 
and sometimes altered contingent on the lines of conversation and current events.

Field notes were taken during interviews or immediately after interviews or conversations in notebooks. Moreover, research notes were taken reflecting thinking about the research. In total, 43 research notes were written, totaling 35,000 words in Chinese. Numerous second-hand data were collected for data triangulation, including policy and planning reports issued by various levels of governments, plus industry marketing materials, news reports, online travelogues and academic literature. The second author also independently raised data for formal governmental reporting.

Both descriptive and thematic coding was used to analyze the data. First, all transcripts were printed out and then read word by word, open codes and notes were written in the blank space while certain words or sentences were highlighted. Meanwhile, the respondents' personal history was summarized on a case-by-case basis. Second, NVivo 11 was used to analyze the data. Again, the transcripts were read word by word, and coding undertaken to identity information with reference to major aspects of the framework. Third, the coded quotations were again referenced to the research and field notes, to identify themes. Last but not least, communication was maintained with key respondents via WeChat to double check the analysis.

Finally, in reporting the findings, the various conversational and textual data are synthesized to develop a number of themes instead of each informant being treated as being ontologically separate (Lamb, 2014). Ethnographic highlights are identified to harness frictional relationships (Tsing, 2005) to uncover the multi-scalar tourism border-making process. Due to the limitation of space, quotations are selected on the basis of their illustrative value for the larger tendencies embedded in the data. Three evolutionary periods of bordering are proposed.

\section{FINDINGS}

\section{Tourism development on the border}


Phase one:

The rapid growth of organized cross-border tourist flow (1991-2001)

After the formation of the People's Republic of China (PRC), the borders were kept tightly closed to prevent outside influences from entering China, which situation remained until the 1980s (Eng, 2000). From the middle 1980s, gaining momentum from the China's "Opening-up" and the decentralization of decision-making permitting border provinces more discretionary powers, the borders were gradually opened up as the provincial and local governments encouraged cross-border trading to boost economic development (Liu \& Lia, 1993). In Banna, border tourism was initiated by local authorities as early as 1991 as an economic development tool. A prefecture official commented:

At that time, we initiated tourism for borderland residents as the breakthrough for tourism, we didn't construct it for tourists, and the certificate for the traveling was border people pass... The border tourism was promoted from the bottom to the top. To be more specific, it's our innovative way to develop borderland economy. Not violating state policy, we somewhat "played edge ball”, launched [border tourism] in the form of border trade.

With China's "opening-up" and consequent rapid economic growth, overseas travel became financially accessible for an emerging middle-upper class in the 1990s (Wang \& Sheldon, 1996), having previously been severely restricted. In fact, it was not until 1997 with the issue of the Provisional Regulation on Self-supported Outbound Travel by Beijing that self-supported outbound leisure travel was formally started. Before then, outbound tours were mostly for business, friends and relatives visits, often associated with restrictions such as overseas family friends having to pay the costs of travel. Moreover, there were few outbound tourism destinations to choose with the Approved Destination Status (ADS) system established relaxing restrictions on outbound tourism market but retaining control by creating a regulatory need for visa approval (Arlt, 2013). Indeed by the end of 1999, mainland Chinese were permitted to visit only nine ADS 
countries for tourist purposes (China National Tourism Administration, 2016).

It was against this backdrop that border tourism program had an appeal as a form of overseas travel. As the prefecture official pointed out, "In the past, the country was not that open, if you could travel overseas, people would think that's extraordinary." This is also reflected in an early government report: Domestic tourist is a magnificent source market for Banna, as long as Banna increases tourism facilities, further develops border tourism, it can attract more domestic tourists (Economy and Technology Research Center of Yunnan Provincial Government, 1993, para.20). According to statistics issued by the Mongla authorities, the tourist numbers for the China-Myanmar border tourism program grew from around 2,000 in 1991 to 207,221 in 1994 to 593,740 in 1999 (Center for Tourism Planning and Research of Sun Yat-sen University \& Banna Tourism Administration, 2003).

Reflecting this growth, the Menghai county government established the Daluo Economic Development Zone, commonly known as the China-Myanmar Street, right on the border with land confiscated from local villagers. After the government built the road and other infrastructure, plots of land were then sold to outside investors. Seeing the business opportunities, Han migrants from the inland soon flocked to the border town, among whom Hunanese and Sichuanese accounted for the largest part. This was due to historical links as during the 1950s and 1960s Hunanese migration to Banna was mobilized by the state to "Support the Construction of Socialism in the Borderland", and in the 1960s and 1970s large numbers of Sichuanese "educated youth" were also sent to Banna. The Han migrants soon dominated tourism building hotels, tourist restaurants, souvenir shops, travel agencies, border trade or even businesses providing for the necessities of daily life (e.g., fashion, and hardware stores). This in turn left the ethnic minorities with smaller service functions (e.g., food vendors) and low-end service jobs (e.g., waitresses and cleaners). However, some of the ethnic minorities took advantage of their land use rights by renting land to investors for tourist development. For instance, one former village official (Dai, 60s) recalled hosting a Beijing investor 
in 1995:

I didn't know him in the beginning, he was introduced ... by his friends. I was the village official then, advertising that we had the forest and wanted to develop it, and that whoever wanted to invest here would be welcomed and could do what he/she wanted. You know, we didn't have money so I needed to find money.

Inevitably inconsistencies between central policies and actual practices emerged. For instance, while the Beijing government demanded that border tourism tourists be limited to residents of the border province itself, in practice border tourism involved tourists from a much broader region and even nationwide in some cases (Zhang, 1996). In Yunnan, the tourist market was opened to provide for tourists from outside the Province (Yunnan Provincial Tourism Administration \& Yunnan Provincial Public Security Department, 1993). Thus, one informant who once worked as a tour guide in the town, recalled:

Informant: It was chaotic at that time [in 1999]. The border pass was hand-written, it was not linked to the internet. As a tour guide, I even took tourists from Taiwan, Japan, and Korea to Mongla, just fabricating a Chinese ID number (laugh).

Author: Could these people pass the port?

Informant: Yes, you know, they looked like Chinese. Just fabricated a Chinese ID number, no photo was needed. The tour guide would take the list to border police and then crossed the border, it was somewhat chaotic.

It was in this stage that the border gained economic value, while an "othering" process occurred between local indigenous on both sides of the border and Han migrants.

Phase two:

Stagnation and collapse of formal tourism sectors yet emerging illegal crossborder tourist flow (2002-2011) 
Since 2000 Chinese outbound tourism experienced extraordinary growth due to China's continuing economic growth and further loosening of controls on outbound tourism (Tse \& Hobson, 2008). This, in turn, adversely affected the popularity of border tourism program as a form of overseas travel, as reflected in Figure 4. A steady decrease in tourist numbers for the border tourism program was undoubtedly observed in Banna around the early 2000s (Center for Tourism Planning and Research of Sun Yat-sen University \& Banna Tourism Administration, 2003).

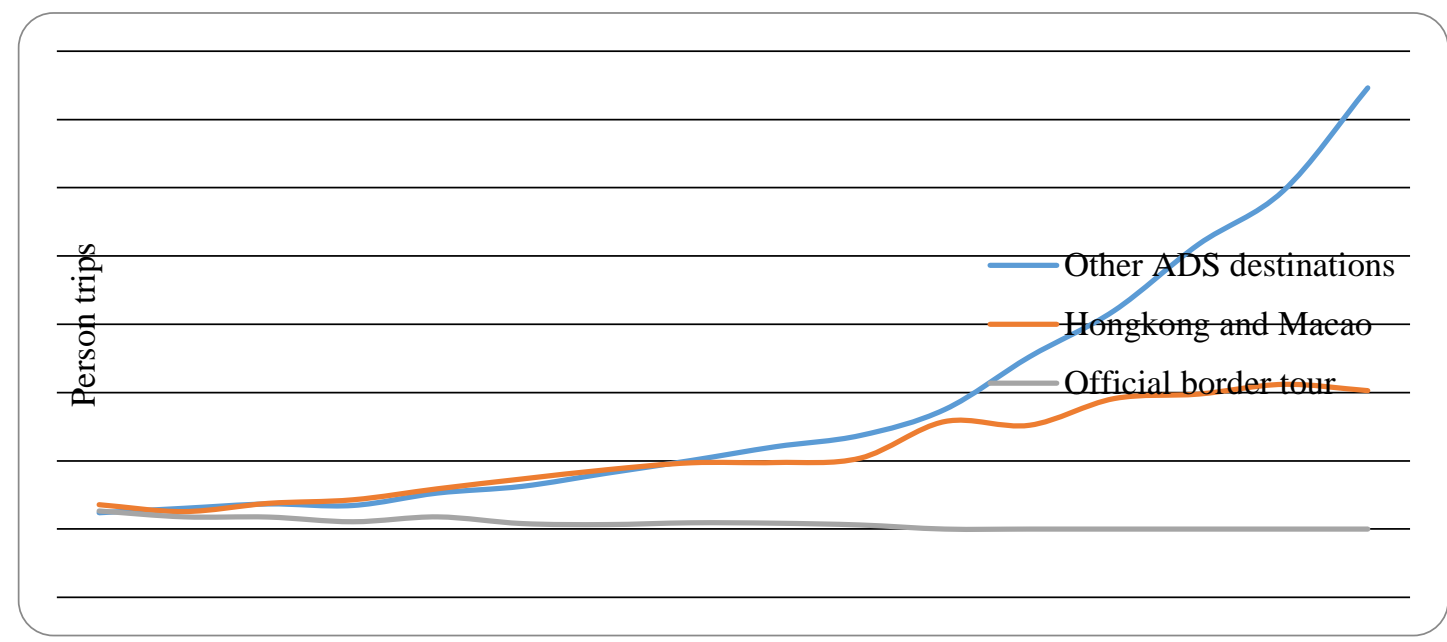

Figure 4 Three types of Chinese outbound tourism organized by travel agencies (2000-2015)

Note: Statistics of official border tour have not been published since 2010

Source: China National Tourism Administration

Meanwhile, what might be termed "vice tourism" based on casinos, prostitution and even drugs emerged in the borderlands of China's neighbors in the late 1990s and early 2000s, notably the borderlands of Myanmar and Vietnam along China's southwestern border as well these of Russia and North Korea along China's northeastern border (Xinhua Net, 2005; Yi, 2003). This catered to Chinese vice-seekers, including corrupt government officials and state-owned enterprise managers (Yi, 2003). Indeed, when casinos first opened in Mongla in 1998, several casinos also opened on the Chinese side, to which the local authorities somewhat turned a blind eye. The casinos were then sustained intermittently till around 2001 when anti-vice policies were more tightly 
implemented (a town official, interviewed in November 2015). Then, when the vice sectors on the Chinese side were forced to shut down, investors simply moved their businesses to Mongla. In its heyday (2004), there were 56 casinos, big and small, in Mongla (Fujimura, 2013). This in turn contributed to an increase in the cross-border flow of Chinese vice-seekers, Mongla turning into a "vice town" with gambling, prostitution and drugs.

The rampant cross-border gambling wave at China's border soon attracted the attention of Beijing. In Yunnan, as early as May 2003, in response to Beijing's deployment, the Yunnan provincial government launched the special "Sword Action" to combat crossborder gambling. In 2004 and 2005, when a nationwide crackdown was deployed by Beijing, the border tourism program was initially suspended in Yunnan in December 2004. Yet the Yunnan government did not halt it entirely for fear of adverse effects on its economy, and it remained available to provincial residents. According to several government informants, it was not until September 2005 that Kunming halted all border tourism programs as the prior policy was not effective and was potentially attracting Beijing's attention. This closure led to a sudden collapse of the formal tourism sectors, not only in the Daluo-Mongla border area, but also the whole of Menghai county. The was not surprising as the area had long relied on Mongla for its tourism, ignoring its own destination building, as commented upon by official and industry respondents. And throughout the process, local Chinese governments frequently appealed to Beijing to resume the program because of the loss of tourism revenues.

With the official border crossing closed for Chinese tourists but remaining open for registered residents of Banna, illegal crossings flourished as a means for outsiders, mostly gamblers, to enter Mongla. As no natural barriers form the border, local villagers, especially those from villages close to the borderline, helped visitors enter Mongla via various small tracks using motorbikes. Indeed, several villages even established routes for illegal border crossing and would charge "customers" for watching out for border 
police, though this practice ceased in 2016 after police raids. The business was profitable and reached a relatively large scale, as verified by various informants' comments. Yet again, local relevant state agencies, to some degree, turned a blind eye to the practice, albeit with occasional short-run crackdowns. In turn, some officials were bribed by villagers for exercising a "kind" tolerance. Villagers frequently mentioned this local corruption and it was also confirmed by official informants.

During this stage the bordering process exhibited tensions between official dictate and local realities, but overtime an increased regulatory practice became the norm, reinforcing the authority of local and central governments.

\section{Phase three:}

Resurrection and transition of border tourism (2012-present)

In the second decade of the twenty-first century, casinos have less presence on China's neighboring borders. The casinos in Mongla town were closed, though some subsequently reopened, but further inland, about $20 \mathrm{~km}$ from the border; the casinos in Boten on the Laos-China border were all shut down by 2011, with some investors shifting their attention to the Laos-Thailand border (Nyíri, 2012). Moreover, Beijing actively sought regional cooperation with neighboring countries, as illustrated by the One Belt, One Road Initiative, and cross-border tourism initiatives are encouraged. This is reflected by changes in terminology being used in various recent governmental policy and planning documents: The term "border tourism" is increasingly accompanied or even replaced by “cross-border tourism”. Table 2 offers a typical example.

Table 2 Word frequency of border tourism related terms in Yunnan provincial fiveyear tourism plans

\begin{tabular}{lccc}
\hline Term & $\begin{array}{c}11^{\text {th }} \text { five-year (2006-2010) } \\
\text { plan issued in 2005 }\end{array}$ & $\begin{array}{c}12^{\text {th }} \text { five-year } \\
(2011-2015) \text { plan } \\
\text { released in 2011 }\end{array}$ & $\begin{array}{c}13^{\text {th }} \text { five-year (2016- } \\
\text { published in 2016 } 2016\end{array}$ \\
\hline Border & 12 & 7 & 62 \\
Border tourism & 8 & 3 & 33 \\
\hline
\end{tabular}




\begin{tabular}{llcc}
\hline Cross-border tourism & 5 & 8 & 88 \\
Border cross-border tourism & 0 & 0 & 4 \\
Cross-border border tourism & 0 & 0 & 5 \\
Cross-nation tourism & 2 & 5 & 10 \\
Regional tourism cooperation & 7 & 4 & 26 \\
\hline
\end{tabular}

While the border tourism program was approved by Beijing to resume nationwide in 2013, it no longer had the appeal of earlier years, either in Banna or elsewhere on China's borders $(\mathrm{Li}, 2014)$. As one prefecture official commented: "Now border tourism business is not as good as it was before, many people travel abroad with passports and are not interested in the border tour, as for travel agencies, it's not really that useful to obtain the designation, so they just don't apply for it." In Banna the local authorities shifted their focus from Mongla to Daluo, with an emphasis now on ethnicity and rurality.

Two features of the redevelopment can be observed. On the one hand, local government seeks to attract large companies with large projects and investments to boost tourism (a county official, interviewed in April 2016). On the other hand, there has been active government intervention in local tourism according to official informants, be it distinctive rural tourism village projects financed by Yunnan provincial government, accelerated infrastructure construction, or the introduction of state-owned enterprise such as Golden Peacock Tourism Group ${ }^{1}$. As indicated in Figure 5, the redevelopment has achieved some success in attracting visitors.

1 Golden Peacock Tourism Group, dating back to the middle 1990s, is the largest tour company initially established by an enterprise controlled by Han interests from Zhejiang Province in East China. In 2009, however, 66\% of its shares were purchased by Yunnan Tourism Investment Group (a provincial government-owned company), making it a state-held company. 


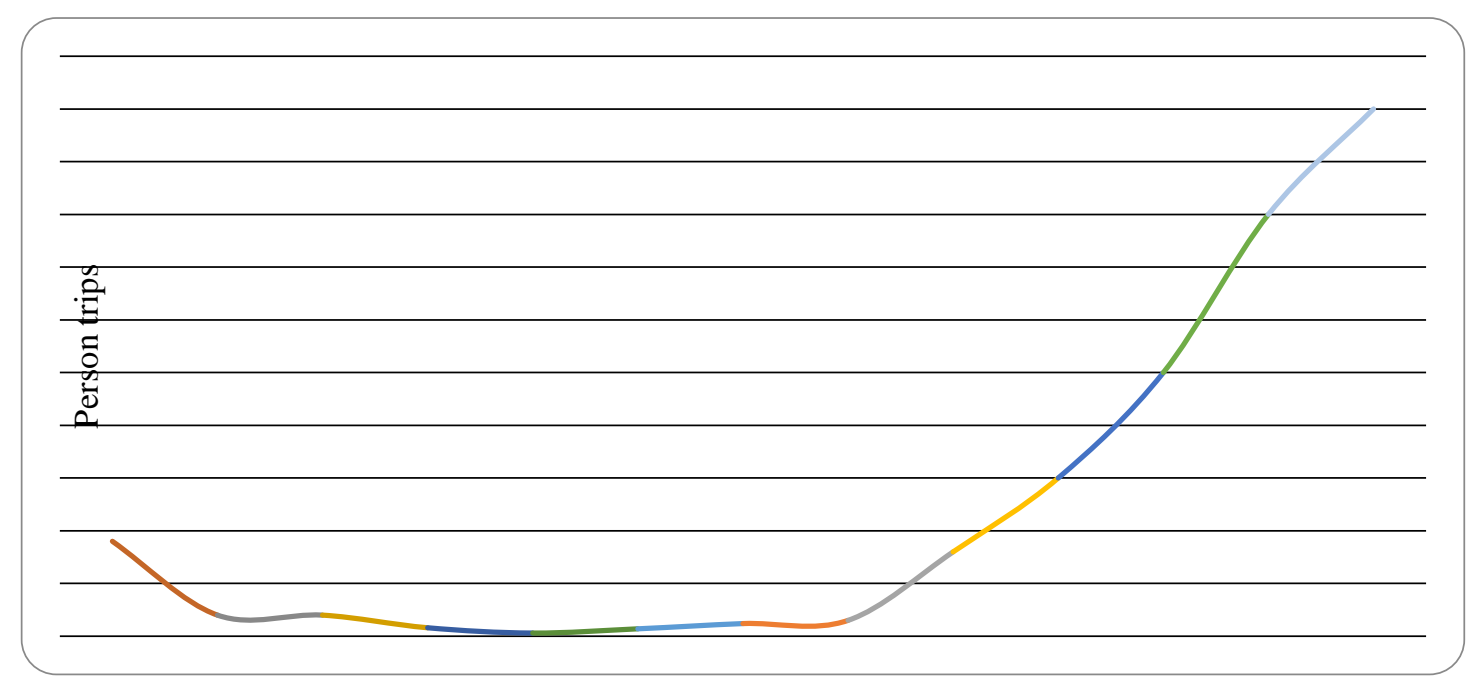

Figure 5 Tourist numbers of Mengjinglai Scenic Site, Daluo

Note: Menjinglai, a cultural park based on a Dai village that presents Dai culture since 2004, is a must-see site in Daluo, thereby its visitor number reflecting the trend of tourism development in the town.

\section{Tourism development as a re-bordering force}

\section{Materialization of the border}

It was not until 1960 that a boundary treaty was signed between China and Myanmar that formalized a border between the two countries (Fan, 2010). Yet few artificial boundary markers were erected, as recalled by villagers, as tall trees, big rocks, and rivers were used as markers. Locals were free to cross the border, and border crossing formalities were few. Indeed, there was little need at the Daluo-Mongla border, as the ban on border trade as well as its remoteness meant little demand for cross-broder traffic until the advent of tourism.

With the development of trade and tourism, things changed. On the one hand, the emerging cross-border flows prompted Chinese state to enhance control and filtering measures, reinforcing a grounded interpretation of "the border". For instance, against the background of China's "opening-up" of the border in the early 1990s, a second joint inspection of China-Myanmar border (1992-1995) was conducted. New boundary 
markers were built, as was the case on the Daluo-Mongla border in 1993. In Yunnan, commencing in 1992, borderland residents were required to apply for PRC exit and entry permits for legal crossing via "border port". As Mongla had been the focus of development and was more prosperous than Daluo, it increasingly became the business, retail and entertainment center for the border region. That was reinforced by investment in roading infrastructure.

Despite this, village residents maintained they continued to illegally use traditional "small tracks" for border crossing until the early 2000s when the crackdown on crossborder gambling began between China and Myanmar in earnest. This was evidenced by troops being again sent to Daluo in 2003 after previously being withdrawn in the middle 1980s (a border official, interviewed in June 2017), in common with other parts of China's borders (Yu, 2014). An army border patrol was established, and border fences and observation towers were built by the Chinese authorities. Locals involved in the illegal border crossing business have been increasingly monitored and punished. In compensation, initiatives are being explored to involve locals in border management and control. One example is the involvement of Yunnan Tourism Investment Group/Golden Peacock Company in promoting a grassroots Party organization on the border as envisaged by the provincial government. The first Alliance Party workstation in Banna comprising local border police, the enterprise and the village was established at Mengjinglai in 2017.

On the other hand, "signing" the border per se as a tourist attraction is a common practice on the ground, promoting the "visibility" of the abstract borderline. Border facilities, such official crossing points and boundary markets, have long become tourist attractions. Moreover, various tourism-oriented places or activities that refer to the border also act as an active reminder of the existence of the border, like "The First Village on China Myanmar Border" and "China-Myanmar Border River Rafting”. To this end, a physical border has become increasingly visible and appreciable among local communities. 


\section{Socio-economic integration of borderlanders}

While tourism initially marginalized local communities, the development of it was linked with other initiatives, notably with banana and rubber plantations. These have significantly involved local residents to their economic advantage. When rubber planting was initiated in the 1950s in Banna, it was mainly limited to state-farms dominated by Han migrants. In the 1980s local authorities started to encourage ethnic minorities to plant rubber for economic development. It was then on a small scale, but that changed in the 1990s and 2000s when outside investors expanded it on a much larger scale (a town official, interviewed in April 2016). Banana plantations were primarily initiated by outside investors in the early 2000s. The main plantation investors are Hunanese and Sichuanese, so verifying the strong link between the general influx of outsiders and the inter-relationship between tourism development and development of banana plantation. An interdependence between tourism and the plantation industry exists in that both are facilitated by and justify State infrastructure development. Equally, each could compensate the other in the case of a downgrading of business in one of the two. The following typifies the relationship.

Case: M6, 38, is a Han migrant from Kunming, Yunnan. He came to work in Daluo as a tour guide in 1998. When the official border tour was suspended, he lost the job. Yet feeling attached to Daluo, he did not leave Daluo. Instead, he chose to stay in Daluo and work for banana plantation and learned the related techniques. Then in 2009, he started to rent land to start his own banana plantation. In the beginning, it was $60 m u$ ( $1 m u=0.0667$ hectare $)$ land, by 2017 it has increased to up to $500 \mathrm{mu}$ land. Yet his story is not unique. Indeed, as far as he knows, there are several others who very successfully shifted from tourism to agriculture after the tourism suspension. After the official border tour was resumed, he also started to work with the Golden Peacock Company. He now has a team of four to market the cross-border tour for the company, mainly targeting at free and independent tourists. 
The rapid development of cash crop plantation raised land rents, which, in turn, provided the indigenous people greater opportunities based on their land usage rights. While initially employed by the outside (Han) investors, some are now becoming employers of the new migrants attracted to the banana plantations in recent years. The following is not untypical (interview with a Dai villager, 20s, in November 2015):

Author: Now people here don't grow rice.

Villager: We usually rent our land out for banana plantations. Now my family has taken the land back and grow bananas by ourselves.

Author: Grow it by yourselves, so you have the skills?

Villager: No, we employ others to do it. There are people who can plant and look after bananas. Give them some commission and let them look after it.

For the indigenous border communities, the transition from traditional sightseeing tour groups toward more independent and experience-seeking travelers in recent years (Banna Tourism Administration \& Monitoring Center for UNWTO Sustainable Tourism Observatories, 2015) has meant that they can bypass intermediaries in parts of a distribution chain currently dominated by Han investors. One recent and visible phenomenon is the emergence of ethnic restaurants and accommodations operated by locals. Often the initiatives are supported by State interventions in business skill education, training and field trips, or the provision of direct financial allocation for facilities and infrastructure improvement.

One consequence is that many enterprises now stress benefit sharing with local ethnic minority communities (research note, June 21, 2017). Notably, in 2015, partly with the help from local government, villagers of Mengjinglai even managed to abolish the previous compensation system agreed in its 50-year-fixed contract signed with the Golden Peacock Tourism Group in the early 2000s. At that time the village was anxious to attract investment and accepted a fixed, low compensation for hosting tourism. The 
village now has the right to share $8 \%$ of the ticket income, which is to rise to $12 \%$ in 2020.

With the establishment of the Banna prefecture, Dai ruling privileges were abolished and all ethnic groups had equal legal rights. Yet on the ground, the old ranking order survived the changes, as the Dai's lowland position facilitated their agricultural production and later involvement in the market economy in the Reform era (Kui, 1997). However, with increased Han immigration, the privileged position of Dai seems to have been eroded as the incoming Han generally have advantages in education, language, capital, and employment history. Additionally, the emerging rubber economy favored the hill tribes who generally manage much of the hill land suitable for rubber plantations, as noted:

Several years ago, rubber price was $35 R M B$ a half kilo. When shopping, Bulang people took big bags of cash, whilst we Dai used really small ones. Each Bulang household has several thousand rubber trees, each day they earned one to two thousand $R M B$, we only earned several dozens (An old Dai villager).

Accordingly, the hierarchical social structure of Dai being privileged and upland ethnic groups being subordinate, has largely dissolved. Another factor is the increasing popularity of ethnic intermarriage, notably the Han-ethnic minority marriages. Thus, as local socio-economic lives are integrated into the Chinese nation-state and more importantly, as the ethnic minorities visibly benefit from such integration, a sense of belonging and pride associated with China has been greatly enhanced.

\section{The "othering" of Mongla}

A trip to another country is often motivated by curiosity, and a desire to seek new things. As one Dai villager commented, "Tourists wanted to cross the border to travel overseas. There was no point for a tourist coming here without traveling overseas." In this instance the Banna tourism industry emphasized and even purposefully created 
differences in Mongla. Many of these were features "imported" from other parts of Myanmar or other Southeast Asian countries, including long neck people, big ear people, and Thai ladyboys. Another notable example is that while local minorities on the Chinese side still refers to Burmese Dai people on the Burmese side as Dai, the industry brochures used the nomenclature "Shan", the official ethnic appellation of the Burmese government. On the ground, this differentiation enhanced the idea of "them" as "Myanmar" separated from local Dai by the border.

From the viewpoint of particularly local Han, what changed their view of Mongla was the growth of its vice sectors. When asked, locals often referred to prostitution, gambling and drugs, depicting Mongla as a place of vice where anything goes and a place to avoid. This perception reinforced notions that the border should be tightly controlled to stop the flow of vice, notably drugs, across the border from Mongla. Given that the vice was associated with a sense of chaos, crime, corruption, and even lawlessness that led to a common belief that "we" have a better socio-political environment than "them". Such a differential contributed to a wider discourse in relation to a "modern" and stable China vis-à-vis a "backward" and chaotic Myanmar.

\section{DISCUSSION AND CONCLUSION}

Drawing on the dynamics of border tourism development and China's broad political economic evolution, one can trace shifting power relationships between the Chinese state, market forces and border communities across the three phases.

At phase one, with decentralization of state power, fiscal policy reform and the establishment of the socialist market economy, local governments were motivated to pursue fiscal income maximization (Oi, 1995). For Beijing, the post-Tiananmen Square policies were driven by the necessity to grow the Chinese economy to maintain political support and legitimacy (Cornet, 2012). In turn, border tourism innovation from the bottom was promoted by the central government as a strategy to reduce regional development differences and stabilize the periphery of the State. Local government 
actively sought to attract outside business and investment, and local governments and private market forces became the dominant players for socio-economic development in the borderland. At this stage indigenous communities were marginalized mainly due to a lack of capital and market linkage. Indeed, the principle of "whoever invests, whoever develops, is the one to profit" was adopted by the Yunnan's tourism administrators at this period (Donaldson, 2007).

Over time, with the emergence of negative tourism impacts including the prominent growth of vice sectors and illegal cross-border flows, the Chinese state responded with tighter regulations to avert the undermining of state stability and security. This led to a decline of private market operations along with Beijing's growth of control over the socio-economic development of the border. This was, in the broader context, consistent with Beijing's drive to re-centralize power included political reforms aimed at strengthening its control of lower-level cadres at the turn of the twenty-first century (Edin, 2003). However, the border communities, making the most of their being on the border and their guanxi with local state institutions on the ground, initially maintained the illegal tourist flow; while the later development of plantations benefited from the tourism infrastructure. In turn this subsequently empowered the indigenous people based on their land usage rights. To this end, a partial power shift occurred that favored local communities and the national state.

At phase three, following Xi Jinping's assumption of the Party leadership after the 18th National Congress of the Communist Party of China, there has been a new phase of political re-centralization, seeing recentralized decision-making and strengthened central control (Kostka \& Nahm, 2017). Notably, tolerance for local action is constrained when it is linked to corruption. Meanwhile, the state has adopted a community-centric economic and social development program (Blaxland, Shang, \& Fisher, 2013). These programs have been enacted since 2000 under the "Program to Develop Border Areas and Improve the Lives of the People There", and further supported with the launch of the One Belt, One Road Initiative (State Council of China, 
2017). For the border communities, these socio-economic-political changes have enabled minorities to better participate in and benefit from the development on the border.

Consequently, what has accompanied the tourism development is a continuous growth of a contested-tensioned state power over the borderlands in general, particularly where non-Han populations are numerous. For national government, the border, whether closed or open, operates as a barrier to ensure state security as stability is the priority for Beijing, whereas, for local jurisdictions, a different discourse is premised on an open border as an economic resource. For the tourism market forces, the border is a line of difference to be utilized in destination marketing and a line to be crossed to experience an imagined "other". For the indigenous communities, the border can be a socioeconomic resource for wanted or unwanted cross-border flows. In the tourism development process, each stakeholder has sought to utilize the border for their own purposes, leading to a boundary on the map becoming a reality in the practices and imaginations of borderland dwellers, and as a material and mental border between "us" and "them". Therefore, the tourism development involves a "re-bordering" of the border. At first glance, this interpretation of the Chinese experience appears to contradict policy-makers' assumption of (cross)border tourism as a de-bordering force, facilitating openness and eroding barrier effects of border, such in the Europe Union (Prokkola, 2010) and Greater Mekong Subregion (Sofield, 2006). This seeming contradiction, in fact, illustrates the importance of scale in understanding border (ing) (Novak, 2016). In this study, on a macro-level, de-bordering appears to be the mainstream following China's opening-up of its borders at phase one, while re-bordering seems to be the trend with nationwide suspension of border tourism and tightening control over the border at phase two, followed by de-bordering with the One Belt, One Road Initiative at phase three. Yet, on the ground it is re-bordering across the three stages.

Conventional studies of liminal regions indicate that tourism development in ethnic minority areas led by state intervention in alliance with capital results in the marginalization of ethnic minorities (Yang et al., 2008; Zhu, Jin, \& Graburn, 2017). 
However, there is a need to consider temporal aspects, and in China what was true even a decade ago is less valid today given the rate of change. China is a dynamic social process, and tourism is part of that process. This study suggests that while initially bypassed by the cross-border tourist flow, the minority communities are increasingly able to participate in and benefit from tourism in the twenty-first century due to structural changes in socio-economic and political environments. Hence, they derive power from the centralized pro-poverty and ethnic minority policies of Beijing to counteract local pro-economic predispositions of local jurisdictions.

This study thus makes several contributions to the literature: (a) It develops an analytical framework to capture tourism border-making and applies it to a Chinese border tourism context. It thus contributes to the understudied tourism and bordering nexus (Rowen, 2014; Timothy et al., 2016), which is of significance to tourism studies and border studies, and establishes a link between the two; (b) It describes the changing power relations among stakeholders to contribute to the understanding of the realpolitik in China's borderland from a tourism borderlands perspective, addressing the previous lack of attention to power relations (Stoffelen et al., 2017), and (c) responds to the call for more longitudinal research in China (Li, Ryan, \& Cave, 2016) regarding tourism development in China's ethnic minority areas.

Borderlands are a nexus of differentiation, where each of the stakeholders impute differing meanings of the role of the border. For tourists it is emblematic of journey into different cultures, for local ethnic minorities it is a disruption of family structures and an imposition on traditional lifestyles. For local administrations it represents a potential source of revenue and costs, for the tourism industry it is an attraction to be capitalized and for the State it is place to be patrolled and for the conduct of diplomatic relationships. Yet each of these possesses potential tensions wherein attitudes and policies may swing from one end of the pendulum to the other - from the open to the closed border, from an othering to the discovery of joint interests - and all the time the border retains a geo-political entity imposed on more diffuse socio-economic and 
political processes. Finally, it is concluded that Kenichi Ohmae (1995, p. 11) assertion that "nation states have already lost their role as meaningful units of participation in the global economy of today's borderless world" is however, not borne out by this example. Rather the border is de-territorialized to become a social political structure that retains importance.

\section{REFERENCES}

Aramberri, J. (2001). The host should get lost: Paradigms in the tourism theory. Annals of Tourism Research, 28(3), 738-761.

Arlt, W. G. (2013). The second wave of Chinese outbound tourism. Tourism Planning \& Development, 10(2), 126-133.

Askew, M., \& Cohen, E. (2004). Pilgrimage and prostitution: Contrasting modes of border tourism in lower South Thailand. Tourism Recreation Research, 29(2), 89-104.

Banna Tourism Administration, \& Monitoring Center for UNWTO Sustainable Tourism Observatories. (2015). Monitoring report on sustainable tourism development in Xishuangbanna (brief version). Guangzhou: Monitoring Center for UNWTO Sustainable Tourism Observatories

Bi, C., \& Yang, W. (2017, March 22). Tourism management for ethnic based tourism community in China, case study in Xishuangbanna. Paper presented at the 2017 International Conference on Management Sciences ( ICoMS 2017) UMY, Indonesia

Bianchi, R. (2018). The political economy of tourism development: A critical review. Annals of Tourism Research, 70, 88-102.

Blaxland, M., Shang, X., \& Fisher, K. (2013). People oriented: A new stage of social welfare development in China. Journal of Social Service Research, 40, 508-519.

Brunet-Jailly, E. (2005). Theorizing borders: An interdisciplinary perspective. Geopolitics, 10(4), 633649.

Center for Tourism Planning and Research of Sun Yat-sen University, \& Banna Tourism Administration. (2003). Strategic research of Banna in GMS tourism cooperation Jinghong: Banna Tourism Administration.

China National Tourism Administration. (2016). The list of ADS countries ( regions) Retrieved from http://www.cnta.com/

China National Tourism Administration, Ministry of Foreign Affairs, Ministry of Public Security, \& General Administration of Customs. (1997). The interim measures for the administration of border tourism. Beijing: Authors

Cornet, C. (2012). The Indigenization of tourism-led modernization: The Dong of Zhaoxing, Southeast Guizhou 1990-2010 (Doctoral thesis). Université Laval, Quebec, Canada Retrieved from http://theses.ulaval.ca/

Dean, K. (2005). Spaces and territorialities on the Sino-Burmese boundary: China, Burma1 and the Kachin. Political Geography, 24(7), 808-830.

Dean, K. (2012). Spaces, territorialities and ethnography on the Thai-, Sino-and Indo-Myanmar boundaries. In D. Wastl-Walter (Ed.), The Routledge Research Companion to Border Studies (pp. 219-241). Farnham: Ashgate. 
Donaldson, J. A. (2007). Tourism, development and poverty reduction in Guizhou and Yunnan. The China Quarterly, 190, 333-351.

Economy and Technology Research Center of Yunnan Provincial Government. (1993). Research on tourism development of Banna Kunming: Author.

Edin, M. (2003). State capacity and local agent control in China: CCP cadre management from a township perspective. The China Quarterly, 173, 35-52.

Eng, K. K. (2000). Negotiating central, provincial, and county policies: Border trading in South China. In G. Evans, C. Hutton \& K. K. Eng (Eds.), Where China meets Southeast Asia (pp. 72-97). Singapore: Institute of Southeast Asian Studies.

Fan, H. (2010). The settlement of China-Burma border dispute: Course and impact. Southeast Asian Affairs, 3, 36-45.

Fetterman, D. M. (2010). Ethnography: Step-by-step. Thousand Oaks: Sage.

Frisvoll, S. (2013). Conceptualising authentication of ruralness. Annals of Tourism Research, 43, 272296.

Fujimura, M. (2013). From the Golden Triangle to the Golden Quadrangle: A basket of new virtues and old sins. Economic Research 5, 105-142.

Ge, Q., Xi, J., \& Wang, S. (2014). Development stages, patterns and key strategic questions regarding border tourism in China. Resources Science, 36(6), 3-10.

Gelbman, A., \& Timothy, D. J. (2017). Differential tourism zones on the western Canada-US border. Current Issues in Tourism, 1-23.

Ghosh, S. (2011). Cross-border activities in everyday life: The Bengal borderland. Contemporary South Asia, 19(1), 49-60.

Government of Banna. (2016). Introduction to Xishuangbanna prefecture. Retrieved from http://www.xsbn.gov.cn/

Hannonen, O. (2017). Bordering the "other": The case of the Finnish-Russian border. FenniaInternational Journal of Geography, 195(1), 113-117.

Herzog, L. A., \& Sohn, C. (2017). The co-mingling of bordering dynamics in the San Diego-Tijuana cross-border metropolis. Territory, Politics, Governance doi.org/10.1080/21622671.2017.1323003

Jacques, M. (2012). When China rules the world: The rise of the middle kingdom and the end of the western world [Greatly updated and expanded]. Harmondsworth: Penguin

Jessop, B. (2008). State power. A strategic-relational approach. Cambridge: Polity.

Johnson, C., Jones, R., Paasi, A., Amoore, L., Mountz, A., Salter, M., \& Rumford, C. (2011). Interventions on rethinking 'the border'in border studies. Political Geography, 30(2), 61-69.

Kostka, G., \& Nahm, J. (2017). Central-local relations: Recentralization and environmental governance in China. The China Quarterly, 231, 567-582.

Kraudzun, T. (2017). Sovereignty as a resource: Performing securitised borders in Tajikistan's Pamirs. Geopolitics, 1-26.

Kui, C. (1997). Relationship changes between lowlander and hill tribes in Xishuangbanna, PR China. Asia Pacific Viewpoint, 38(2), 161-167.

Lamb, V. (2014). "Where is the border?" Villagers, environmental consultants and the 'work'of the ThaiBurma border. Political Geography, 40, 1-12.

Li, B. (2009). "Abolished"tourism town : Phenomenon and preventive treatment-based on an empirical study of Daluo Town National Grade Port in Yunnan Province. Tourism Tribune, 24(1), 65-70. 
Li, C. (2014). The rise and decline of Wanding, Daluo on the China-Myanmar border World Knowledge (19), 73-73.

Li, P., Ryan, C., \& Cave, J. (2016). Chinese rural tourism development: Transition in the case of Qiyunshan, Anhui.-2008-2015. Tourism Management, 55, 240-260.

Li, Y., \& Shu, S. (2015). Focus on frontier research in China under the perspective of tourism. Geographical Research, 34(3), 407-421.

Liu, B., \& Lia, J. (Eds.). (1993). The liberation of border region and the markets of the neighbouring countries. Beijing: Legal Publishing House.

Mansfeld, Y., \& Korman, T. (2015). Between war and peace: Conflict heritage tourism along three Israeli border areas. Tourism Geographies, 17(3), 437-460.

Megoran, N. (2012). Rethinking the study of international boundaries: A biography of the KyrgyzstanUzbekistan boundary. Annals of the Association of American Geographers, 102(2), 464-481.

Newman, D. (2006). The lines that continue to separate us: Borders in ourborderless' world. Progress in Human geography, 30(2), 143-161.

Novak, P. (2016). Placing borders in development. Geopolitics, 21(3), 483-512.

Nyíri, P. (2012). Enclaves of improvement: Sovereignty and developmentalism in the special zones of the China-Lao borderlands. Comparative Studies in Society and History, 54(3), 533-562.

Ohmae, K. (1995). The end of the nation state: The rise of regional economies. New York: Free Press.

Oi, J. C. (1995). The role of the local state in China's transitional economy. The China Quarterly, 144, 1132-1149.

Prokkola, E.-K. (2010). Borders in tourism: The transformation of the Swedish-Finnish border landscape. Current Issues in Tourism, 13(3), 223-238.

Rossiter, D. A. (2011). Leave the lemons at home: Towards a political ecology of border space. Geopolitics, 16(1), 107-120.

Rowen, I. (2014). Tourism as a territorial strategy: The case of China and Taiwan. Annals of Tourism Research, 46, 62-74.

Ryan, C. (2012). Researching indigenous and marginal peoples-Introduction. In K. F. Hyde, C. Ryan \& A. G. Woodside (Eds.), Field guide to case study research in tourism, hospitality and Leisure (pp. 411-415). Bingley: Emerald Group Publishing.

Scott, J. W. (2015). Bordering, border politics and cross-border cooperation in Europe. In F. Celata \& R. Coletti (Eds.), Neighbourhood Policy and the Construction of the European External Borders (pp. 27-44). Basel: Springer.

Singh, S. (2014). Borderland practices and narratives: Illegal cross-border logging in northeastern Cambodia. Ethnography, 15(2), 135-159.

Sofield, T., \& Li, S. (2011). Tourism governance and sustainable national development in China: A macro-level synthesis. Journal of Sustainable Tourism, 19(4-5), 501-534.

Sofield, T. H. (2006). Border tourism and border communities: An overview. Tourism Geographies, 8(2), 102-121.

State Council of China. (2017). Planning for the Program to Develop Border Areas and Improve the Lives of the People There during the Thirteenth Five-Year Plan period Beijing: Author.

Stoffelen, A., Ioannides, D., \& Vanneste, D. (2017). Obstacles to achieving cross-border tourism governance: A multi-scalar approach focusing on the German-Czech borderlands. Annals of Tourism Research, 64, 126-138.

$\mathrm{Su}, \mathrm{X}$. (2010). The imagination of place and tourism consumption: A case study of Lijiang Ancient Town, 
China. Tourism Geographies, 12(3), 412-434.

Timothy, D. J. (2001). Tourism and political boundaries. London: Routledge.

Timothy, D. J., Guia, J., \& Berthet, N. (2014). Tourism as a catalyst for changing boundaries and territorial sovereignty at an international border. Current Issues in Tourism, 17(1), 21-27.

Timothy, D. J., Saarinen, J., \& Viken, A. (2016). Editorial :Tourism issues and international borders in the Nordic Region. Scandinavian Journal of Hospitality and Tourism, 16(Supplement 1), 1-13.

Tse, T. S., \& Hobson, J. P. (2008). The forces shaping China's outbound tourism Journal of China Tourism Research, 4(2), 136-155.

Tsing, A. L. (2005). Friction: An ethnography of global connection. Princeton: Princeton University Press.

Van Schendel, W., \& De Maaker, E. (2014). Asian borderlands: Introducing their permeability, strategic uses and meanings. Journal of Borderlands Studies, 29(1), 3-9.

Wang, Y., \& Sheldon, P. J. (1996). The sleeping dragon awakes: The outbound Chinese travel market. Journal of Travel \& Tourism Marketing, 4(4), 41-54.

Weidenfeld, A. (2013). Tourism and cross border regional innovation systems. Annals of Tourism Research, 42, 191-213.

Weng, S. (2011). The impact of power relationship to the societies of the ancient villages and towns: Cases studies from Wuzhen and Furong village at Nanxi river basin (Doctoral thesis). Sun Yat-sen University, Guangzhou,China.

Xie, L. (2005). Research on the development of border tourism in Western China. Tropical Geography 25(2), 181-184.

Xinhua Net. (2005). Our nation cracks down hard on outbound gambling, promotes "people's war" against gambling. Retrieved from http://www.news.cn/

Yang, L., Wall, G., \& Smith, S. L. (2008). Ethnic tourism development: Chinese government perspectives. Annals of Tourism Research, 35(3), 751-771.

Yi, H. (2003, Feburary). Overseas gambling casinos "besiege" China South Reviews (4), 27-30.

$\mathrm{Yu}$, H. (2014). Various efforts drove mainland China to restart border tourism in Yunnan Phoenix Weekly $9(502), 42-43$.

Yunnan Provincial Tourism Administration, \& Yunnan Provincial Public Security Department. (1993). Notice about the administration of China-Vietnam, China-Laos, China-Myanmar border tourism of Yunnan Province. Kunming: Authors.

Zhang, G. (1996). Background and brief development process of Chinese border tourism. Review of Economic Research(H6), 8-11.

Zhu, Y., Jin, L., \& Graburn, N. (2017). Domesticating tourism anthropology in China. American Anthropologist, 119(4), 730-735. 